To Maega | Jurnal Pengabdian Masyarakat

Bulan-Tahun, Vol.3, No.2, hal.83-91

$\operatorname{ISSN}(P): 2622-6332 ; \operatorname{ISSN}(E): 2622-6340$

http://www.ojs.unanda.ac.id/index.php/tomaega

\title{
Peluang Wirausaha Mandiri melalui Diversifikasi Olahan Kelapa
}

\author{
Jumarniati1,a, Muhammad Rusli Baharuddin 2,b,", Wakifatul Hisani ${ }^{3, c}$ \\ ${ }_{1}^{1}$ Pendidikan Matematika, FKIP, Universitas Cokroaminoto Palopo \\ ${ }_{2}^{2}$ Pendidikan Guru Sekolah Dasar, FKIP, Universitas Cokroaminoto Palopo \\ ${ }^{3}$ Agroteknologi, Faperta, Universitas Cokroaminoto Palopo \\ a,b,cEmail: jumarniati_22@yahoo.co.id; mruslib@gmail.com; wakifatulhisanisani@gmail.com \\ *Correspondent Email: mruslib@gmail.com
}

Article History:

Received: 20-06-2020; Received in Revised: 08-07-2020; Accepted: 15-07-2020

DOI: http://dx.doi.org/10.35914/tomaega.v3i2.381

\begin{abstract}
Abstrak
Mitra dalam PKM ini adalah Kelompok Tani Kelapa Kecamatan Bone-Bone, Kabupaten Luwu Utara, Sulawesi Selatan yang membudidayakan tanaman kelapa dan mengolahnya menjadi Kopra. Permasalahan yang dihadapi mitra yaitu rendahnya nilai jual kelapa dan olahan kelapa (Kopra) belum mampu mengangkat perekonomian petani serta keberadaan limbah kelapa berupa air kelapa, pelepah dan daun yang menyebabkan terjadinya pencemaran lingkungan dan menjadi sarang hama. Berdasarkan permasalahan tersebut, tim pelaksana menawarkan alternatifik solusi berupa Prospek Wirausaha Mandiri melalui Diversifikasi Olahan Kelapa. Bentuk kegiatan dari PKM Petani Kopra ini adalah Pendampinagn Pembuatan dan Pemanenan nata de coco dan Pelatihan Kewirausahaan dan Pengemasan Produk. Target Luaran dari kegiatan PKM ini adalah peningkatan pengetahuan mitra dalam membuat nata de coco, Pengemasan produk, manajemen pemasaran dan dasar-dasar akuntasi keuangan. Selain itu, lahir wirausaha baru skala home industry berbasis potensi daerah dan meningkatnya pendapatan petani kelapa.
\end{abstract}

Kata Kunci: Limbah Kopra, Wirausaha Mandiri, Nata de coco

\begin{abstract}
Partners in the Community Partnership Program are the Coconut Farmers Group in Bone-Bone District, North Luwu Regency, South Sulawesi, which cultivates coconut plants and processes them into Copra. Processed palm oil has not been able to lift farmers by using coconut water, midribs and leaves that cause environmental pollution and become a den of pests. Based on these considerations, the implementation team offered an alternative solution in the form of an Independent Entrepreneurial Prospect through Processed Coconut Diversification. The form of activities of the Copra Farmers Community Partnership Program is the nata de coco Production and Harvesting Assistant and Entrepreneurship and Product Packaging Training. The target of the output of this Community Partnership Program activity is to increase the knowledge of Partners in making nata de coco Product packaging, marketing management and the basics of financial accounting. In addition, a home-based industry scale entrepreneurship was based on regional potential and coconut farmers income allocation
\end{abstract}

Key Word: Copra Waste, Independent Entrepreneur, Nata de coco 


\section{Pendahuluan}

Indonesia merupakan negara penghasil kelapa terbesar di dunia, dengan luas lahan perkebunan mencapai 3,6 juta hektare dan jumlah produksi sebesar 2,8 juta ton per tahun. sebagian besar merupakan perkebunan rakyat seluas 3,729 ribu ha $(98,18 \%)$ sisanya milik negara seluas 5,5 ribu ha $(0,14 \%)$ dan perkebunan milik swasta seluas 64 ribu ha $(1,68 \%)$, dengan total produksi sebesar 2.247 ribu ton kopra. (Badan Pusat Statistik, 2018)

Sebagai sentra penghasil kelapa dunia, Indonesia memiliki enam provinsi yang menjadi utama area produksi kelapa, antara lain Riau dengan produksi tahunan mencapai 419.000 ton, Sulawesi Utara 270.000 ton, Jawa Timur 259.000 ton, Maluku Utara 231.000 ton, Jawa Tengah 181.000 ton, dan Sulawesi Selatan 167.000 ton. (Badan Pusat Statistik, 2018)

Mitra dalam PKM ini adalah Kelompok Tani Kelapa Kecamatan BoneBone, Kabupaten Luwu Utara, Sulawesi Selatan. Kabupaten Luwu Utara merupakan sentra produksi kelapa terbesar di Sulawesi Selatan. Salah satu kecamatannya adalah Bone-Bone. Hal ini ditunjukkan dengan jumlah produksi yang tinggi pada tahun 2018 yaitu sebesar 8.428,50 ton dengan luas tanam seluas 5.869 ha. Produktivitas tanaman kelapa mencapai 2.700 - 4.500 kelapa butir yang setara $0,8-1,2$ ton kopra/ha dan berpotensi ditingkatkan menjadi 6.750 butir atau setara 1,5 ton kopra.

Umumnya, areal penanaman kelapa oleh mitra yaitu dengan memanfaatkan pematang perkebunan dan pertambakan. Benih yang digunakan adalah berasal dari tanaman pohon induk yang telah memasuki umur sekitar 20-40 tahun lamanya. Tingkat produksi buah yang sekitar 80 - 120 buah/pohon/tahun atau dengan perkiraan lain sekitar $25 \mathrm{~kg} /$ pohon/tahun.

Kelapa yang dihasilkan oleh mitra kemudian diolah menjadi kopra dan batok kelapa dijual untuk dijadikan sebagai aran pembakaran. Selain itu, Kebiasaan suku Makassar-Bugis menjadikan kelapa sebagai bahan baku dalam proses pembuatan makanan sehari-hari.

Peningkatan produksi dan manajemen usaha petani kelapa terus dilakukan pemerintah daerah Kabupaten luwu Utara untuk mendukung Kecamatan BoneBone menjadi sentra produksi kelapa melalui Badan Pemberdayaan Masyarakat, Perempuan dan Keluarga Berencana (BPPKB). Program Peningkatan produksi dan manajemen usaha petani dilakukan dengan menghadirkan penyuluhan teknis budidaya kelapa, pemupukan dan pemilihan benih, serta inovasi produk. Bantuan modal juga dikucurkan melalui bantuan dana bergulir dan kredit bunga ringan atau pinjaman bersubsidi.

Pemanfaatan buah kelapa menjadi kopra secara ekonomi dan manajemen usaha belum maksimal jika dibandingkan dengan potensi sumberdaya kelapa. Potensi sumberdaya kelapa menjadi agribisnis yang kuat akan tercapai jika petani mampu mengolah kelapa menjadi produk bernilai ekonomi tinggi dan mengolah 
keberadaan limbah pengolahan kopra. Keberadaan limbah kelapa berupa air kelapa, pelepah dan daun yang jumlahnya sangat besar menjadi permasalahan tersendiri karena berpotensi menyebabkan terjadinya pencemaran lingkungan dan menjadi sarang hama.

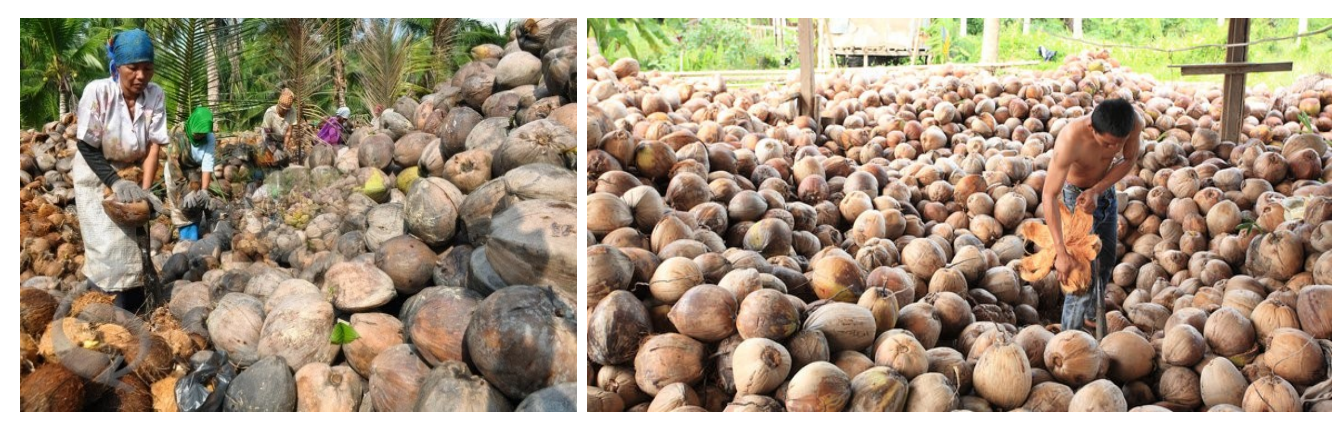

Gambar 1. Produktivitas Kelapa Mitra PKM

\section{Metode}

\section{a. Langkah-langkah dalam melaksanakan solusi dari permasalahan mitra.}

Bidang produksi dan manajemen melakukan pelatihan dan pendampingan pembuatan nata de coco, pendampingan proses pemanenan nata, dan sosialisasi pengolahan limbah kopra. Sedangkan bidang pemasaran yaitu melakukan pelatihan pengemasan produk dan pelatihan kewirusahaan.

\section{b. Metode Pendekatan}

Metode Pendekatan yang ditawarkan bagi realisasi program PKM kelompok petani kelapa (Kopra) adalah penyuluhan atau diskusi bersama mitra, pelatihan pembuatan nata de coco, pengemasan dan kewirausahaan, dan Pendampingan lapangan. Penerapan metode pendekatan bersifat partisipatori dalam artian bahwa tim pengusul bersama mitra secara proaktif terlibat dalam setiap kegiatan.

\section{c. Partisipasi Mitra}

Bentuk partisipasi mitra dalam kegiatan ini adalah (1) Bersama-sama mengidentifikasi permasalahan petani kelapa (Kopra), (2) Menyiapkan sarana dan prasarana pelatihan, (3) Mengikuti penyuluhan dan diskusi tentang prosfek peluang wirausaha madiri. (4) Mengikuti sosialisasi tentang pengolahan limbah kopra, (5) Mengikuti pelatihan pembuatan pupuk organik bokashi, (6) Mengikuti Pelatihan Pembuatan nata de coco dari limbah air kelapa, (7) mengikuti pelatihan pengemasan produk, (8) mengikuti pelatihan kewirusahaan, dan (9) Melakukan sosialisasi kepada masyarakat sekitar maupun petani kelapa (kopra) yang lain mengenai cara pembuatan nata de coco, pengolahan limbah kelapa/Kopra, dan pengemasan produk yang baik. 


\section{d. Evaluasi pelaksanaan program dan keberlanjutan program setelah selesai kegiatan PKM dilaksanakan.}

Evaluasi Pelaksanaan program dengan melakukan (1) monitoring terhadap kuliatas dan kuantitas nata de coco, standar pengemasan produk yang praktis dan higeinis, (2) Mengecek secara berkala tentang perkembangan dan melakukan pendampingan lapangan secara intensif, (3) Evaluasi program akan dilakukan secara bertahap dengan memperhatikan setiap aspek tahapan kegiatan yang telah dilakukan sebagai indikator keberhasilan program yang secara internal dan eksternal, dan (4) Melakukan desiminasi hasil kegiatan melalui seminar hasil dengan mengundang stakeholders setempat, media cetak maupun elektronik.

\section{Hasil dan Pembahasan}

\section{a. Diversifikasi Olahan Kelapa}

Kegiatan diversifikasi olahan limbah air kelapa menjadi nata de coco dilaksanakan dari tanggal $7 \mathrm{~s} / \mathrm{d} 14$ Agustus 2019. Kegiatan ini memberikan pengetahuan bagi masyarakat khususnya ibu PKK dan Ibu Tani Kelapa tentang bagaimana cara pembuatannya, mulai dari pembuatan nata sampai pada proses pemanenan Nata.

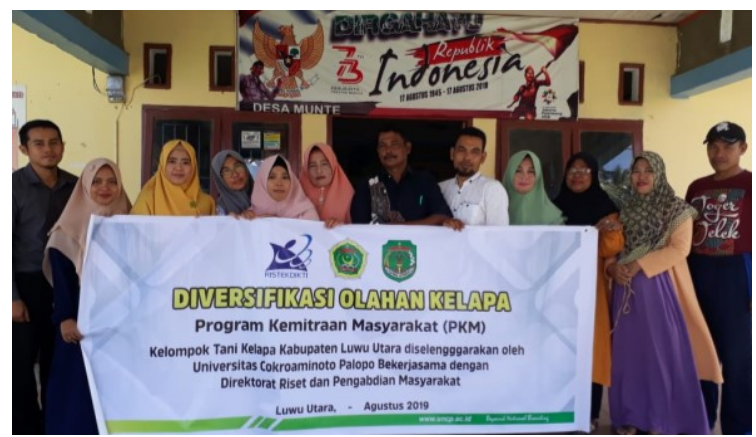

Gambar 2. Pembuatan nata de coco

Alat dan bahan yang digunakan dalam pembuatan nata de coco yaitu sebagai berikut: Alat: panci, kompor, toples kaca, saringan, gelas ukur $1000 \mathrm{ml}$, botol spray, pipet tetes, pengukur ph, dan termometer. Bahan: alkohol 70\%, air kelapa, asam asetat glasial, gula, starter (bakter acetobacter xylinum), magnesium sulfat (MgSO4), amonium sulfat (NH4)2SO4, alumunium foil, tissu, kertas koran, dan kertas label.

Cara Pembuatan: (1) Menyiapkan seluruh alat dan bahan yang digunakan, (2) Menghaluskan buah dengan menggunakan blender dengan perbandingan 1:3 (daging buah buah: air). (3) Memasak sari buah hingga mendidih menggunakan api kompor gas. (4) Menyaring sari buah mengunakan saringan, lalu ambil sebanyak $450 \mathrm{ml}$ (5) Memasak ulang sari buah yang telah disaring dengan memasukkan Amonium sulfat sebanyak 0,06\%, Magnesium sulfat 0,03\%, dan gula (variasi perlakuan $10 \%, 9 \%$, dan $8 \%$ ) lalu aduk hingga bercampur selama 5 menit (6) Membiarkan larutan menjadi agak dingin dan menuangkan larutan 
kedalam toples yang sebelumnya telah dituangkan starter Acetobacter xylinum sebanyak $50 \mathrm{ml}$. Kemudian mengaduknya hingga starter tercampur merata dengan larutan (7) Menutup toples dengan menggunakaan aluminium foil steril lalu beri lubang. Selanjutnya menutupnya lagi dengan kertas koran steril. Toples, Aluminium Foil, dan koran telah disterilkan sebelumnya menggunakan alkohol 70\%. (8) Melakukan pengukuran rendemen awal (Menimbang toples dan isinya) (9) Menginkubasi selama 14 hari. (10) Pada hari ke 14 dilakukan perhitungan rendemen nata dengan cara menimbang kembali toples beserta isinya.
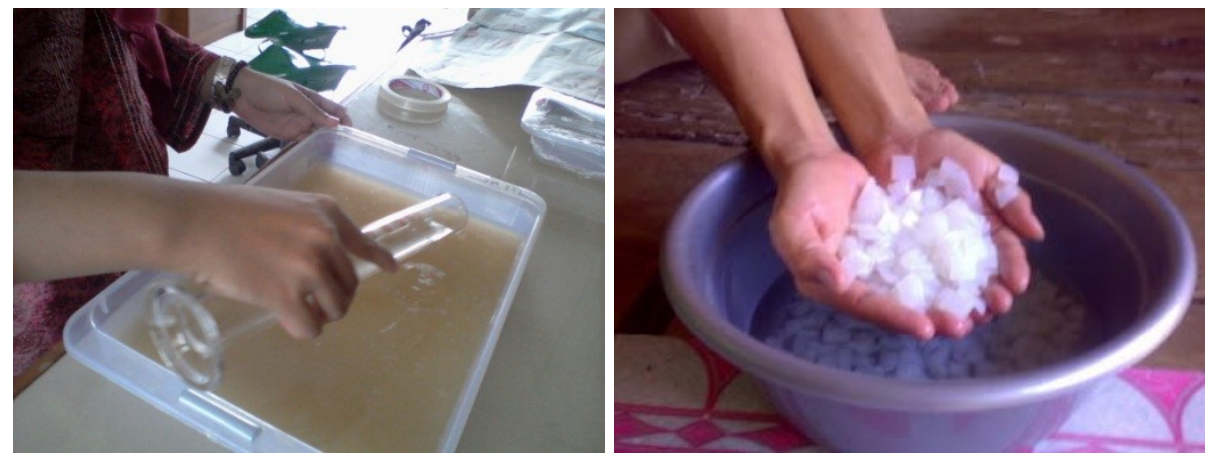

Gambar 3. Proses Pembuatan dan Pemanenan Nata

Pemanenan Nata: (1) Mengangkat lapisan putih pada permukaan atas (nata) dengan menggunakan garpu atau alat lain yang steril. (2) Membuang selaput tipis pada bagian bawah nata. (3) Memotong nata berbentuk kubus seragam dan mencuci hingga bersih. (4) Merendam nata selama 2- 3 hari dengan mengganti air secara rutin. (5) Untuk menghilangkan rasa asam yang melekat.dan (6) Memasak nata dengan larutan gula pasir $20 \%$ atau 200 gram / liter air.

\section{b. Pelatihan Kewirausahaan dan Pengemasan Produk}

Pelatihan dan Pendampingan kewirausahaan dilakukan setiap pekan selama 2 bulan (19 Agustus - 19 Oktober 2020), dalam pelaksanaannya kelompok petani kelapa (Kopra) dibekali dengan keterampilan manajemen produksi. Secara terurut materi pendampingan yang diberikan petani kelapa (Kopra) yaitu perencanaan wirausaha Baru, pengemasan produk, Pengelolaan keuangan, dasardasar akuntasi keuangan, analisis pasar dan perluasan pemasaran sebagai bentuk kesiapan menjadi wirausaha mandiri.
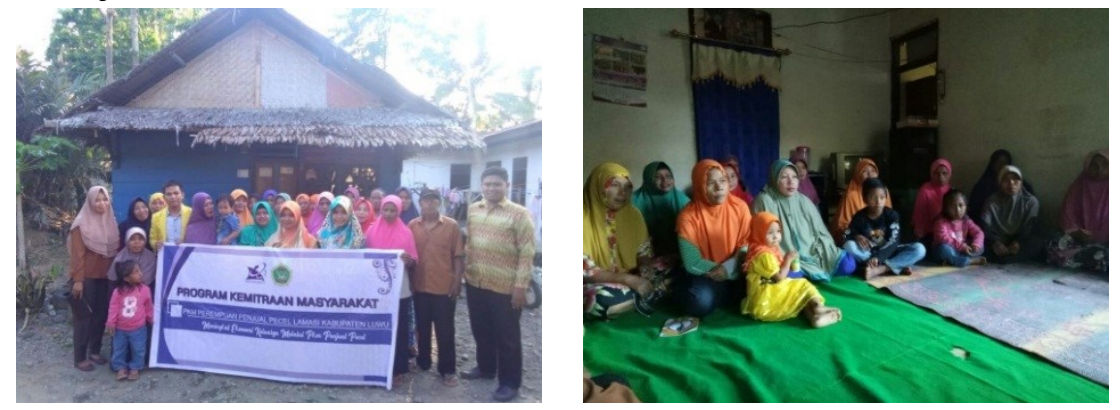

Gambar 4. Pelatihan Kewirauhaan 
Selain pelatihan kewirausahaan petani kelapa (Kopra) juga dibekali pelatihan pengemasan produk. Bentuk pelatihan pengemasan produk dilakukan dengan melakukan praktek secara langsung mulai dari membersihkan kemasan, mamastikan tidak bertumbuhnya bakteri, memilih desain yang kreatif dan inovatif, sampai pada uji ketahan kemasan.

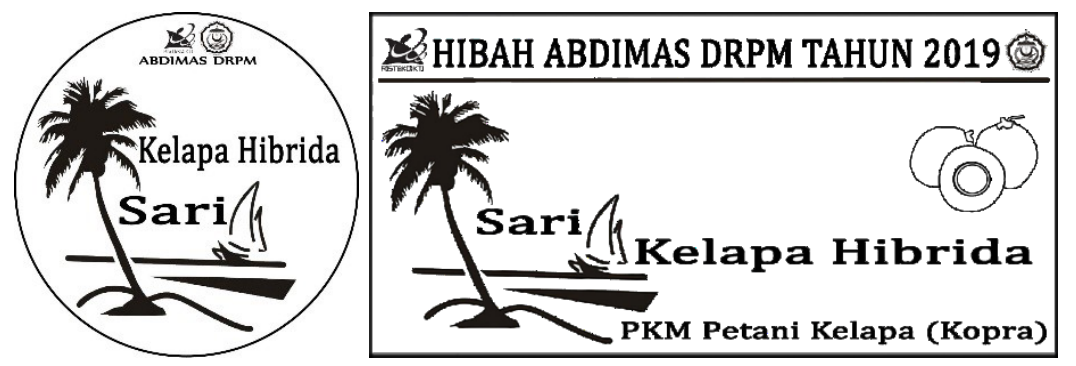

Gambar 5. Desain Kemasahan nata de coco

Pengasaman produk nata de coco dilakukan dengan menambahkan asam sitrat sehingga $\mathrm{pH}$ produk akhir berkisar 3 - 4. Pada tingkat keasaman ini, proses pas-teurisasi bertujuan untuk membunuh mikroba pembentuk spora, yang dapat menyebabkan kebusukan pada produk. Selain itu, pengujian kemasan produk juga dilakukan melalui uji ketahanan panas, yang akan memberikan informasi kepada mitra, tingkat dan suhu yang tepat untuk dilakukan pengesama.

\section{c. Ketercapaian Program}

Nata de coco mula-mula dikenal di Filipina yaitu produk olahan yang terbuat dari air kelapa dengan bantuan mikro-organisme yang terkenal sangat baik untuk diet makanan berserat di Indonesia "nata de coco" telah berkembang sebagai home industry dimana teknologi pengolahannaya baik dari air maupun nira kelapa telah tersedia (Damanik 2015). Nata de coco yang dihasilkan umumnya diolah lebih lanjut menjadi makanan pencuci mulut. Pengolahan nata de coco sebagai makanan pencuci mulut sudah banyak dilakukan oleh industri pangan, yaitu dengan cara mengemasnya sehingga lebih awet (Hakimi dan Budiman 2012). Nata de coco dalam kemasan dibuat dengan penambahan sirup gula dengan atau tanpa penambahan bahan tambahan pangan yang diizinkan, kemudian dikemas secara aseptik (Nurhayaty, 2006).

Proses pengemasan nata de coco dilakukan dengan merebusnya untuk menghilangkan sisa asam, memotong/mengirisnya sehingga berukuran kecil, mengisikannya ke dalam kemasan plastik, menambahkan larutan sirup gula, dan mengawetkannya dengan proses termal pada suhu dan waktu tertentu (Hakimi dan Budiman, 2012). Di dalam proses produksi nata de coco dalam kemasan tersebut, tahapan yang penting adalah proses termal. Proses ini bertujuan untuk membunuh mikroba patogen dan pembusuk yang berpotensi tumbuh selama penyimpanan, sehingga produk aman dikonsumsi dan dapat disimpan lebih lama (Heldman and Singh, 2013). 
Dari aspek pemasaran, fakta dilapangan menunjukkan bahwa tingginya permintaan terhadap nata de coco menjelang bulan suci ramadhan merupakan peluang usaha skala home industry. Selain itu, nata de coco dapat juga dijadikan sebagai oleh-oleh khas luwu timur. Melihat Peluang usaha nata de coco maka dapat dijadikan solusi perekonomian keluarga dengan manargetkan wirausaha mandiri berbasis potensi daerah.

Upaya menciptakan wirausaha mandiri berbasis potensi daerah perlu didukung oleh sumberdaya yang siap bersaing. Sehingga kelompok petani kelapa (Kopra) sebagai calon wirausaha maka dibekali pelatihan kewirausahaan agar mampu mengelola potensi sumberdaya, melihat peluang pasar, dan mengembangkan pemasaran. Sejalan dengan itu Syahyuti (2007) mengungkapkan bahwa seseorang dapat dikatakan sebagai wirausahawan apabila mempunyai kemampuan melihat dan menilai peluang, mengelola sumber daya yang dibutuhkan serta mengambil tindakan yang tepat, guna memastikan sukses secara berkelanjutan. Namun demikian, perbedaan antara seorang yang memiliki jiwa sebagai seorang wirausaha dengan seorang yang hanya melakukan wirausaha sebagai pekerjaan/hal biasa terletak pada cara dalam membeli, mengolah, menghasilkan dan memasarkan barang/jasa.

\section{Kesimpulan}

Program Kemitraan Masyarakat bagi Petani Kelapa Bone-Bone Kabupaten Luwu Utara dilaksanakan melalui pelatihan dan pendampingan pembuatan nata de coco, pendampingan proses pemanenan nata, sosialisasi pengolahan limbah kopra pelatihan pengemasan produk, dan pelatihan kewirusahaan. Target Luaran dari kegiatan PKM ini adalah peningkatan pengetahuan petani kelapa (Kopra) dalam membuat nata de coco Pengemasan produk, manajemen pemasaran dan dasardasar akuntasi keuangan. Selain itu, lahir wirausaha mandiri berskala home industry berbasis potensi daerah dan meningkatnya pendapatan petani kelapa (Kopra).

Program Kemitraan Masyarakat bagi Petani Kelapa Bone-Bone Kabupaten Luwu Utara langkah awal dalam mewujudkan kemandrian daerah dengan meningkatkan pendapatan petani kelapa. Upaya mewujudkan Kemandrian daerah dengan menciptakan sebanyak mungkin wirausaha baru sebagai penopang perekonomian keluarga. Diharapkan bagi pemerintah setempat, untuk dapat menindaklanjuti kegiatan ini dengan memfasiltasi masyarakat dalam mengembangkan produk unggulan lokal seperti memfasiltasi dalam pemasaran antar daerah, membantu pengurusan ijin, dan memberikan bantuan sarana dan prasarana penunjang. 


\section{Ucapan Terimakasih}

Terima Kasih kepada Direktorat Riset dan Pengabdian Masyarakat, Direktorat Jenderal Penguatan Riset dan Pengembangan. Kementrian Riset, Tekonologi, dan Pendidikan Tinggi atas bantuan pendanaan untuk menunjang terlaksananya program kemitraan masyarakat bagi petani kelapa (Kopra). Komitmen penuh juga diberikan oleh Universitas Cokroaminoto Palopo dengan proaktif dalam memastikan terlaksananya kegiatan dan ketercapaian target luaran dan tujuan kegiatan. Terkhusus Kelompok petani kelapa (Kopra) Kabupaten Luwu Utara, kami memberikan apresiasi setinggi-tingginya atas partipasi aktif selama kegiatan berlangsung.

\section{Daftar Pustaka}

Badan Pemberdayaan Masyarakat, Perempuan dan Keluarga Berencana. 2015. Materi Rapat Pemberdayaan Perempuan 2015. Kota Palopo, Sulawesi Selatan. Tidak diterbitkan

Badan Pusat Statistik Kabupaten Luwu Utara. (2018). Kabupaten Luwu Utara dalam Angka. Luwu Utara: Badan Pusat Statistik Kabupaten Luwu Utara.

Baharuddin, M. R., Hidayati, G. S., \& Amir, B. (2019). Pemberdayaan Masyarakat Marannu melalui Pertanian dan Peternakan Terintegrasi dalam Rangka Mewujudkan Kabupaten Pinrang Sebagai Poros Utama Pemenuhan Pangan Nasional. CARADDE: Jurnal Pengabdian Kepada Masyarakat, 1(2), 99-104.

Damanik, S. (2015). Strategi Pengembangan Agribisnis Kelapa (Cocos Nucifera) untuk Meningkatkan Pendapatan Petani di Kabupaten Indragiri Hilir, Riau. Perspektif, 6(2), 94-104.

FAO. 2018. The State of World Fisheries and Aquaculture 2018. http://www.fao.org/documents/card/en/c/I9540EN/

Hakimi, R., \& Budiman, D. (2012). Aplikasi Produksi Bersih (Cleaner Production) Pada Industri Nata de coco. Jurnal Teknik Mesin, 3(2), 89-98.

Heldman DR, Singh RP. 2013. Introduction to Food Engineering. Edisi 5. London: Academic Press.

Jumarniati, J., Saruman, S. H., \& Baharuddin, M. R. (2019). Perempuan Penjual Pecel Lamasi, Kecamatan Lamasi, Kab. Luwu Sulawesi Selatan Sebagai Pilar Ekonomi Keluarga. CARADDE: Jurnal Pengabdian Kepada Masyarakat, 1(2), 105-110.

Kasmad, R. Kebijakan Pemerintah dan Pemberdayaan Masyarakat: Studi Kasus Program Gernas Kakao di Luwu Utara. https://www.academia.edu/search?utf8=0\%E2\%9C\%93\&q=kelapa 
Nurhayaty N, Lisdiyanti P, Winarni. 2006. Studi Mikroflora pada Proses Fermentasi Nata de coco Santan dan Air Kelapa. Pusat Penelitian Bioteknologi LIPI, Cibinong. Prosiding Seminar Nasional Bioteknologi (P60. 314-315).

Srihidayati, G., Baharuddin, M. R., \& Masni, E. D. (2018). Pemberdayaan Kelompok Tani melalui Peningkatan Nilai Guna Rumput Laut Gracilaria SP. di Kecamatan Wara Timur Kota Palopo. JMM (Jurnal Masyarakat Mandiri), 2(2) 154-162.

Tim Teknis Pembangunan Sanitasi. 2010. Pemberdayaan Masyarakat dengan Pelibatan Jender dan Kemiskinan dalam Pembangunan Sanitasi Kota. Masamba, Sulawesi Selatan. Tidak diterbitkan 